\title{
MENINGKATKAN KETERAMPILAN MENULIS HASIL OBSERVASI MENGGUNAKAN TEKNIK POHON FAKTOR DALAM PEMBELAJARAN BAHASA INDONESIA DI KELAS $X$ SMA NU AL FUDLOLI GANJARAN GONDANGLEGI MALANG TAHUN PELAJARAN 2018/2019
}

\author{
M. Mujtaba, Yusron Yusuf \\ Institut Agama Islam Al Qolam Malang \\ mujtaba0996@gmail.com, nizayusuf@gmail.com
}

\begin{abstract}
Writing is one of the language skills used to communicate indirectly. Writing skills cannot come automatically without regular practice. Based on observation, writing is a difficult activity for some students. This can be seen in the learning activities of writing observations in class X of Al Fudloli NU high school which is still lacking. The use of the factor tree technique is one technique whose implementation is the same as the spider web technique. The technique is only to write the main ideas or keywords to be developed into written observations in the form of paragraphs. The application of this technique begins with dividing groups, assigning each group to make observations outside the classroom, and developing the results in the classroom. The purpose of this research are: (1) describe the results of writing observations of class X students of Al Fudloli NU High School, (2) describe the application of factor tree learning techniques in writing observations, and (3) describe student learning outcomes in writing observations using factor tree techniques in Indonesian subjects in class X of Al Fudloli NU High School. Based on the results of this class action research it can be concluded: (1) pre-cycle there are 5 students who get grades in accordance with KKM and 15 students get grades below KKM or only 25\% are in accordance with KKM and 75\% who are under KKM, (2) the application of the factor tree technique that is by looking for the main ideas first then finding derivatives or sub-subjects that are in the shade of the main ideas, then developing the main ideas and sub-topics into sentences and combining them into paragraphs, (3) The results in the first cycle increased in value from 20 students 12 students got grades in accordance with KKM and 8 students were still below KKM. Thus it can be concluded that the writing skills of the results of initial observations of class $\mathrm{X}$ students have increased by $35 \%$, initially only $25 \%$ of students who were in accordance with KKM. In the first cycle there are $60 \%$ of students who are in accordance with KKM, with an average grade of 69.5. The results of the second cycle increased in value from 20 students to 20 students got grades in accordance with KKM. Thus it can be concluded that writing skills from the observations of class X students have increased by $40 \%$, initially only $60 \%$ of students were in accordance with KKM on the first cycle, and there were $100 \%$ of students who were in accordance with KKM in the second cycle with an average grade 84.25. Thus the application of the factor tree technique can improve writing skills of students' observations.
\end{abstract}

Keywords: Improve, Write Observation Results, Factor Tree Techniques.

\section{PENDAHULUAN}

Menulis adalah suatu kegiatan yang bisa digunakan untuk berkomunikasi, meluapkan apresiasi, inspirasi, dll. Menurut McCrimmon, menulis merupakan kegiatan menggali pikiran dan perasaan mengenai suatu subjek, memilih hal-hal yang akan ditulis, menentukan cara menuliskannya sehingga pembaca dapat memahaminya dengan mudah dan jelas. Pendapat tersebut hampir sama dengan pendapat Mary S. Laurence yang menyatakan bahwa menulis 
adalah mengomunikasikan apa dan bagaimana pikiran penulis. ${ }^{1}$ Menulis merupakan satu keterampilan berbahasa yang dipergunakan untuk komunikasi secara tidak langsung, tidak secara tatap muka dengan orang lain, ${ }^{2}$ seperti menggunakan surat, short message sending, dan lain sebagainya. Menurut Tarigan menulis adalah menurunkan atau melukiskan lambanglambang grafik untuk menggambarkan suatu bahasa dipahami oleh seseorang, sehingga orang lain dapat membaca lambang-lambang grafik itu. ${ }^{3}$

Menulis mempunyai hubungan erat dengan komponen bahasa lainnya, seperti hubungan menulis dengan membaca, hubungan menulis dengan berbicara. Menulis dan membaca mempunyai hubungan yang sangat erat, bila kita menulis sesuatu, kita pada prinsipnya ingin agar tulisannya dibaca oleh orang lain, paling sedikit dapat kita baca sendiri. ${ }^{4}$ Sedangkan hubungan antara menulis dan berbicara, keduanya memiliki ciri-ciri yang sama yaitu produktif dan ekspresif. Perbedaannya ialah bahwa dalam menulis diperlukan penglihatan dan gerakan tangan, sedangkan dalam berbicara diperlukan pendengaran dan pengucapan. Dengan perkataan lain, menulis merupakan komunikasi tidak langsung, tidak tatap muka, sedangkan berbicara merupakan komunikasi langsung, komunikasi tatap muka. ${ }^{5}$

Dalam pembelajaran Bahasa Indonesia, peserta didik diharapkan memiliki keempat keterampilan berbahasa yang mana keempat keterampilan tersebut saling berkaitan dan merupakan satu kesatuan. Keempat keterampilan tersebut harus menjadi perthatian bagi guru, karena bahasa dijadikan suatu alat komunikasi. Oleh karena itu guru harus mengarahkan pembelajaran Bahasa Indonesia pada pengembangan kompetensi berbahasa dan bersastra peserta didik melalui kegiatan mendengar, membaca, berbicara, dan menulis. Pengembangan kompetensi ini diharapkan dapat menjadi bekal bagi peserta didik untuk berkomunikasi dalam kehidupan bermasyarakat secara cerdas, santun, dan bermartabat melalui penguasaan, pemahaman, dan keterampilan menggunakan teks, baik lisan maupun tulis. ${ }^{6}$

Dalam kegitan menulis ini, penulis haruslah terampil memanfaatkan grafologi, struktur bahasa, dan kosa kata. Keterampilan menulis ini tidak akan datang secara otomastis, tetapi harus melalui latihan dan peraktik yang banyak dan teratur. ${ }^{7}$ Serta pendidikan yang terprogram. ${ }^{8}$ Menurut beberapa ahli ciri-ciri tulisan yang baik adalah tulisa yang jujur (jangan mencoba memalsukan gagasan atau ide anda), jelas (jangan membingungkan para pembaca), singkat (jangan memboroskan waktu para pembaca), usahakan keanekaragaman (panjang kalimat yang beranekaragam, berkarya dengan penuh kegembiraan). ${ }^{9}$ Mengenai tulisan yang baik, Alton C. Morris beserta rekan-rekannya mengemukakan pendapat sebagai berikut:

\footnotetext{
${ }^{1}$ Kundaru Saddono, Slamet.Pembelajaran Keterampilan Berbahasa Indonesia. Yogyakarta: Graha Ilmu. 2014.hal 151

${ }^{2}$ Tarigan. Menulis Sebagai Suatu Keterampilan Berbahasa. Bandung: Angkasa Bandung. 2008. hal 3

${ }^{3} \mathrm{Hal} 22$

${ }^{4}$ Tarigan. Menulis Sebagai Suatu Keterampilan Berbahasa. Bandung: Angkasa Bandung. 2008. hal 04

${ }^{5}$ hal 12

${ }^{6}$ Suherli. Maman.dkk. Bahasa Indonesia.Pusat Kurikulum dan Perbukuan, Balitbang, Kemendikbud. 2017 hal III

${ }^{7}$ Tarigan. Menulis Sebagai Suatu Keterampilan Berbahasa. Bandung: Angkasa Bandung. 2008. hal 04

${ }^{8}$ hal 09

${ }^{9}$ hal 07
} 
"tulisan yang baik merupakan komunikasi pikiran dan perasaan yang efektif. Semua komunikasi tulis adalah efektif atau tepat guna". ${ }^{10}$

Salah satu keterampilan menulis kelas $\mathrm{X}$ semester satu yaitu menulis laporan hasil observasi. Namun pada kenyataannya keterampilan peserta didik dalam hal menulis terutama menulis hasil observasi masih sangat kurang, hal ini bisa dilihat dari hasil pembelajaran yang masih banyak belum tuntas, belum memenuhi KKM yang sudah ditetapkan dalam KD tersebut.

Berdasarkan hasil pengamatan peneliti terhadap kegiatan belajar mengajar di kelas baik dalam pelajaran Bahasa Indonesia maupun pelajaran yang lainnya. Dari kegiatan yang dilakukan peneliti menemukan beberapa kekurangan, yaitu: 1) siswa siswi kelas X SMA NU Al Fudloli masih belum terbiasa dengan kurikulum yang terbaru, sehingga masih tertanam ciri khas kurikulum yang sebelumnya. Oleh karena itu, masih ada rasa malas menulis, mengomunukasikan, dan lain sebagainya yang berkaitan dengan ciri khas dari kurikulum yang baru., 2) masih ada beberapa guru yang belum mengetahui dan belum menerapkan kurikulum yang baru, sehingga siswa-siswi selalu mengingat kurikulum yang lama dan terkadang membeda-bedakan kurikulum yang baru dengan kurikulum yang lama, 3) setiap ada guru yang bertanya kepada peserta didik, selalu saja peserta didik yang pandai yang menjawab pertanyaan guru tersebut, dan guru jarang memberikan batas kepada anak yang pandai untuk menjawabnya sehingga tidak ada kesempatan bagi peserta didik yang kemampuannya masih berada di bawah untuk menjawab atau mengembangkan pendapatkan., 4) siswa-siswi SMA NU Al Fudloli masih malu untuk menulis karena kurangnya motifasi dari pihak yang terkait.

Berdasarkan hasil penelitian tersebut, peneliti berusaha menerapkan suatu teknik pembelajaran yang inovatif, karena peneliti adalah seorang guru di SMA NU Al Fudloli Ganjaran sekaligus sebagai Wali Kelas X SMA NU Al Fudloli. Selain itu kreativitas dan keberhasilan menulis sangat bergantung pada metode yang digunakan oleh pengajar. ${ }^{11}$ Oleh sebab itu, peneliti berusaha menggunakan metode dan teknik yang tepat, inovatif, kreatif, menarik dan menyenangkan supaya kegiatan belajar mengajar tidak membosankan.

Teknik adalah cara sistematis mengerjakan sesuatu. Dalam pelajaran Bahasa Indonesia, teknik ini mengacu pada implementasi perencanaan pembelajaan bahasa indonesia didepan kelas $^{12}$. Teknik pohon faktor adalah teknik yang sesuai dengan metode belajar aktif dan kreatif. Metode belajar aktif dan kreatif adalah metode yang berpusat pada siswa atau mahasiswa, bukan pada pengajar. ${ }^{13}$ Metode ini juga sesuai dengan tuntutan kurikulum 2013 yang mana kegiatan belajar mengajar berpusat pada siswa tidak lagi ada di guru, dalam k13 guru hanyalah pendamping dan tidak berperan secara aktif. Sedangkan teknik pohon faktor menuntut siswa untuk aktif, kreatif, dan menyenangkan. Teknik pembelajaran pohon faktor adalah suatu teknik yang berusaha diterapkan oleh peneliti kepada siswa kelas X SMA NU Al Fudloli Ganjaran tanpa harus menyimpang dari aturan pondok pesantren yang diterapkan.

Dengan Teknik ini kami berharap mampu menjadi guru yang diharapkan, sekaligus mampu membentuk siswa kelas X SMA NU Al Fudloli menjadi pribadi yang lebih baik lagi.

\footnotetext{
${ }^{10}$ hal 07

${ }^{11}$ Sutanto, leo. Mencerahkan Bakat Menulis. Jakrta: Kompas Gramedia. 2014. hal 14

${ }^{12}$ Asih. Strategi pembelajaran bahasa indonesia.Bandung: Pustaka Setia. 2016. hal 115

${ }^{13}$ Sutanto, leo. Mencerahkan Bakat Menulis. Jakrta: Kompas Gramedia. 2014. Hal 22
} 
Serta peserta didik diharapkan lebih mudah dalam mengembangkan ide, pikiran, gagasan, dan lebih semangat dalam menulis. Selain itu, dengan teknik pohon faktor diharapkan kegiatan pembelajaran lebih hidup dan menyenangkan. Dari permasalahan di atas, peneliti mengambil judul "Meningkatkan Keterampilan Menulis Hasil Observasi dengan Menggunakan Teknik Pohon Faktor dalam Pembelajaran Bahasa Indonesia di Kelas X SMA NU Al Fudloli Ganjaran Gondanglegi Malang Tahun Pelajaran 2018/2019”.

Penelitian ini bertujuan: 1) mendeskripsikan hasil menulis observasi siswa kelas X SMA NU Al Fudloli, 2) mendeskripsikan penerapan teknik pembelajaran pohon faktor dalam menulis observasi, dan 3) mendeskripsikan hasil belajar siswa dalam menulis hasil observasi dengan menggunakan teknik pohon faktor pada mata pelajaran bahasa Indonesia di kelas $\mathrm{X}$ SMA NU Al Fudloli.

\section{METODE PENELITIAN}

Jenis penelitian ini merupakan penelitian tindakan kelas (PTK) di SMA NU Al Fudloli Ganjaran. Penelitian tindakan kelas (PTK) berbeda dengan penelitian kelas (PK).

PTK adalah jenis penelitian yang praktis dan dimaksudkan untuk memperbaiki pembelajaran di kelas. Penelitian adalah tidakan atau proses untuk memecahkan masalah dengan cara runtut, berdasarkan data, mempunyai prosedur yang jelas untuk menemukan data atau hasil secara tepat. Tindakan adalah prilaku seseorang. Sedangkan kelas adalah tempat kegiatan belajar mengajar. Arikunto menjelaskan PTK secara lebih sistematis menjadi 3 bagian, yakni ${ }^{14}$ : (1) penelitian, penelitian merupakan kegiatan mencari suatu objek dengan menggunakan cara dan aturan atau metodologi tertentu untuk menemukan data yang akurat. (2) Tindakan, tindakan adalah gerakan yang dilakukan dengan sengaja dan terencana dengan tujuan tertentu. (3) Kelas, kelas adalah tempat di mana terdapat sekelompok peserta didik yang dalam waktu bersamaan menerima pelajaran dari guru.

Sedangkan penelitian kelas (PK) yaitu pengujian terhadap RPP peneliti yang mana guru diposisikan sebagai objek penelitian. Wina Sanjaya mengatakan bahwa faktor pendorong penelitian kelas biasanya didorong dari keinginan untuk mengetahui atau mengembangkan sesuatu. Sehingga dalam penelitian kelas guru berperan hanya sebagai objek penelitian, yang terkadang hasilnya tidak bisa dirasakan oleh guru itu sendiri. ${ }^{15}$

Dengan demikian, dapat disimpulkan bahwa PTK melibatkan peneliti secara langsung dalam kegiatan belajar mengajar, sedangkan penelitian kelas (PK) peneliti tidak terlibat langsung dalam kegiatan belajar mengajar, peneliti hanya menjadi pengamat.

Pengertian di atas, memperkuat jenis penelitian yang diangkat, karena peneliti terlibat secara langsung, dan penelitian ini perlu dilakukan karena seorang guru atau calon guru mempunyai PR besar dari pemerintah yakni meningkatkan kualitas dan kuantitas pendidikan di Indonesia sehingga mampu menjadikan generasi indonesia menjadi generasi emas yang telah disebutkan dalam kurikulum K13.

Dalam melakukan penelitian tindakan kelas, terdapat lima model yang bisa kita gunakan untuk menjalankan sebuah PTK. Model-model tersebut antara lain: ${ }^{16}$ (1) model kurt lewin, model ini ada 4 tahap yang harus dilakukan yaitu: perencanaan, tindakan, observasi dan

\footnotetext{
${ }^{14}$ Suyadi. Panduan Penelitian Tindakan Kelas. Jogjakarta: Diva Press. 2015. hal 18

${ }^{15}$ Wina Sanjaya. Penelitian Tindakan kelas. Jakarta: Prenadamedia Group. 2015. hal 27

${ }^{16} \mathrm{Hal} 48$
} 
refleksi. (2) model ebbut, model ini berawal dari gagasan terlebih dahulu, lalu temuan, perencanaan, tindakan, monitoring, refleksi, revisi. (3) model Elliot, model ini hamper sama dengan model ebbut, yaitu berawal dari gagasan utama, setelah itu eksplorasi, rencana, tindakan, monitoring. (4) model Hopkins, model ini bermula dari merasakan adanya masalah, menyusun perencanaan, melaksakan tindakan, observasi dan refleksi. (5) model siklus, model ini berawal dari refleksi, melakukan studi pendahuluan, perencanaan, melakukan tindakan, observasi dan refleksi.

Berdasarkan pengertian tersebut, peneliti memilih mengunakan model siklus, dan menggunakan 2 siklus. Alurnya seperti bagan berikut:

Tahap Awal : Refleksi hasil belajar observasi dan wawancara dengan siswa berkaitan dengan masalah yang dihadapi dalam menulis laporan hasil observasi

Perencanaan

Tindakan 1
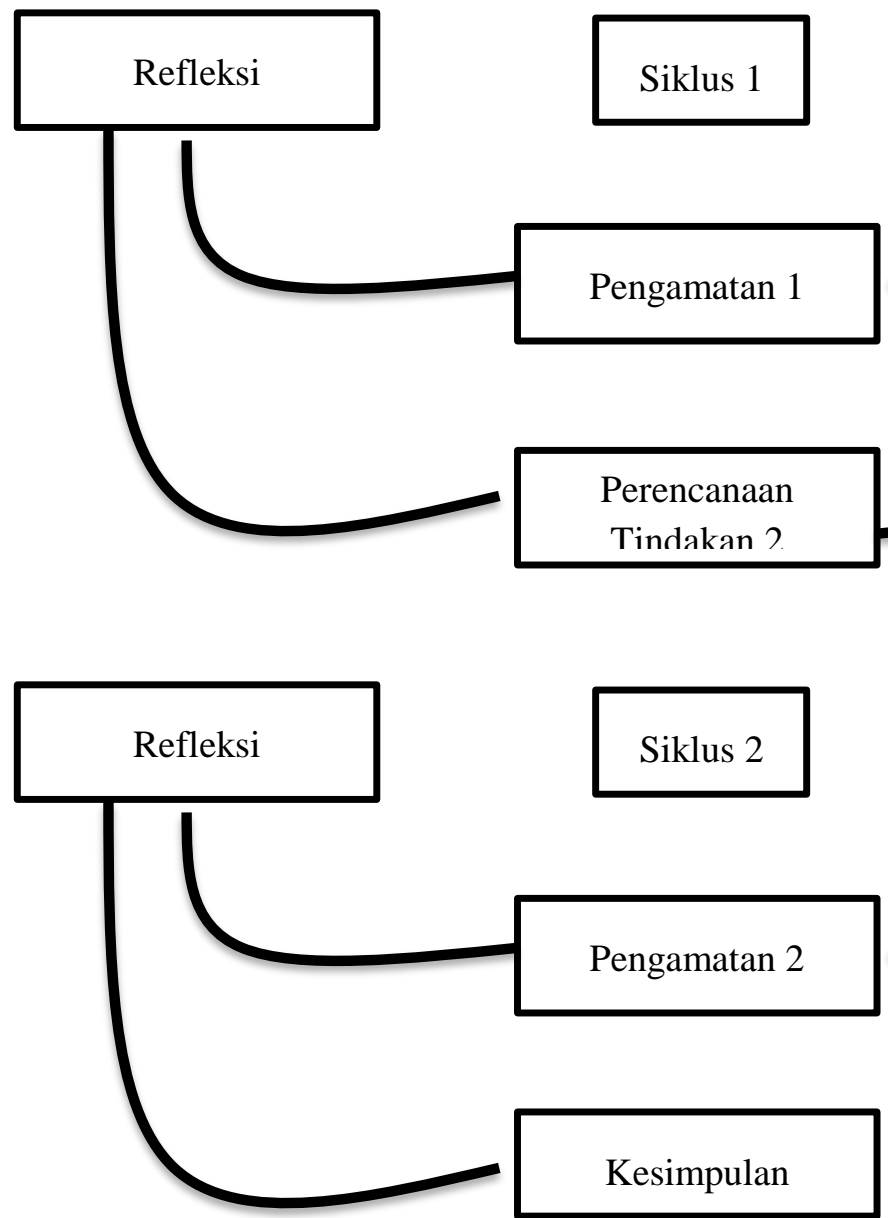

Siklus 2

Pengamatan 2

Kesimpulan 


\section{Siklus 1}

\section{Perencanaan tindakan kelas}

Perencanan tindakan kelas dilakukan sebelum tindakan diberikan kepada peserta didik. Perencanaan juga bisa dilakukan setelah tindakan, biasanya dilakukan setelah mengevaluasi kegiatan dalam kelas untuk merencanakan kegiatan yang lebih baik dalam pertemuan selanjutnya.

Dalam hal ini seorang guru yang menjadi penyusun rancangan perlu menentukan rumusan masalah yang perlu mendapat perhatian khusus untuk diamati, kemudian pada saat proses pembelajaran sedang berlangsung perlu membuat catatan-catatan kecil merekam fakta yang terjadi. Berikut rician yang ada dalam perencanan tindakan kelas: 1) peneliti menyiapkan RPP, teknik pohon faktor yang dilakukan diluar kelas dengan objek kajian lingkungan sekolah untuk mengobservasi dan menjadikannya sebuah laporan hasil observasi, 2) peneliti menyiapkan Instrumen berupa lembar pengamatan, penilaian, catatan lapangan, dan kamera untuk mengambil foto dalam setiap kegiatannya.

Pelaksanaan tindakan kelas adalah tindakan atau perlakuan yang dilaksanakan oleh peneliti berdasarkan perencanaan yang telah disusun. Tindakan inilah yang menjadi inti dari PTK, karena tindakan ini dilakukan sebagai upaya meningkatkan kenerja guru untuk menyelesaikan masalah dan meningkatkan kemampuan siswa dalam menulis hasil observasi. Proses ini dilakukan dengan langkah-langkah sebagai berikut: 1) peneliti memberikan salam, apresiasi beserta motivasi, 2) peneliti materi materi singkat tentang menulis hasil observasi dengan teknik pohon factor, 3) peneliti memberikan siswa kesempatan untuk bertanya mengenai materi dan teknik yang dipilih, supaya peserta didik tidak mengalami kebingungan dalam kegiatan ini, 4) peneliti membagi siswa dalam beberapa kelompok sesuai dengan keadan dan situasi kelas, 5) setiap kelompok berdiskusi mengenai objek apa yang akan diteliti, 5) setiap kelompok membagi tugas untuk mencari ide-ide atau sub-sub objek yang telah disepakati, 6) setelah itu peserta didik mengumpulkan tugas kedalam tugas kelompok untuk diskusi lanjutan dan dijadikan runtutan atau turunan dari objek yang diteliti, 7) peserta didik mulai menulis hasil laporan berdasarkan turunan yang telah dibuat, 8) peserta didik diminta maju dan mengkomunikasin hasil kerja kelompoknya, peneliti dan peserta didik melakukan refleksi.

Pengamatan dilakukan ketika kegiatan sedang berlangsung untuk mengumpulkan informasi tentang proses kegiatan pembelajaran yang dilakukan oleh peneliti. Dalam hal ini, orang yang mengamati dapat mencatat berbagai kelebihan dan kelemahan peneliti dalam melaksakan tindakan. Sehingga dapat memperbaiki kekurangan dalam kegiatan yang akan datang.

Refleksi dilakukan dengan melakukan diskusi dengan observer yang biasanya dilakukan oleh teman sejawat, dan bagi seorang guru yang menjadi observer adalah guru itu sendiri. Dari hasil ini, peneliti dapat mencatat berbagai kekurangan yang perlu diperbaiki, sehingga dapat menjadikan bahan untuk menyusun rencana kegiatan pembelajaran pada pertemuan berikutnya menjadi lebih baik. 


\section{Siklus 2}

Siklus 2 ini merupakan penyempurnaan atau perbaikan dari hasil refliksi siklus 1 .

\section{Perencanaan tindakan}

Dalam hal ini peneliti menyusun ulang atau memperbaiki rencana pembelajaran, menyusun instrumen tes dan nontes, lembar penilaian, catatan lapangan yang digunakan untuk mengamati pembelajaran.

Pelaksanaan tindakan pada siklus 2 ini meliputi: 1) peneliti memberikan apresiasi, 2) peneliti menjelaskan ulang mengenai materi dan teknik yang digunakan, 3) peneliti membagi peserta didik ke dalam kelompok dan diberikan tugas kelompok, 4) peneliti mengarahkan peserta didik untuk keluar kelas dan mngamati objek kajian yang telah disepakati oleh kelompok, 5) peseta didik mulai mengerjakan tugas sampai menjadi tulisan hasil observasi dengan waktu yang telah ditetapkan, lalu dikumpulkan dan dinilai oleh peneliti, 6) peneliti dan peserta didik melakukan refleksi mengenai kegiatan pembelajaran yang telah dilakukan.

Peneliti mengamati dan mencatat perubahan tindakan dan sikap peserta didik dalam kegiatan pembelajaran yang sedang berlangsung. Yang diamati adalah semua peserta didik yang menjadi objek penelitian.

Refleksi ini dilakukan untuk mendapatkan kesimpulan dari pelaksanaan kegiatan pembelajaran. Dalam tahap ini, peneliti diharapkan dapat mengetahui jawaban tentang peningkatan dan perubahan tingkah laku dan sikap peserta didik serta mengetahui apakah teknik ini bisa meningkatkan hasil belajar siswa tentang menulis laporan observasi.

Penelitian ini dilakukan peneliti pada saat kegiatan pembelajaran Bahasa Indonesia dikelas X SMA NU Al Fudloli Ganjaran Gondanglegi Malang. Identifikasi awal dilakukan untuk mengetahui masalah-masalah yang dihadapi siswa dalam kegiatan menulis terutama menulis hasil observasi dikelas X SMA NU Al Fudloli.

Peneliti mengambil setting penelitian di SMA NU Al Fudloli Ganjaran karena disekolah ini masih minim sarana dan prasarana, sehingga dengan hasil penelitian diharapkan dapat membangkitkan motivasi guru dan siswa dalam kegiatan belajar mengajar, khususnya pembelajaran Bahasa Indonesia, serta dapat berkompetensi dengan sekolah unggulan yang terletak dikota. Selain itu peneliti adalah seorang guru disekolah tersebut sekaligus menjadi wali kelas dikelas yang akan dijadikan objek penelitian.

Dalam Melakukan sebuah penelitian sangat penting adanya data, karena data mengabsahkan sebuah penelitian. Maka dari itu peneliti mengumpulkan data dari beberapa sumber, yakni 1) data primer adalah data yang diperoleh secara langsung dari lapangan. Dalam hal ini, peneliti menggunakan hasil pengamatannya dalam kelas ketika kegiatan belajar mengajar sedang berlangsung, selain itu ada juga data dari kepala sekolah, 2) data sekunder adalah data yang memperkuat data primer. Dalam hal ini, peneliti menggunakan buku-buku yang sesuai dengan judul penelitian sebagai refrensi.

Untuk mencapai segala sesuatu yang di inginkan perlu adanya teknik untuk mengumpulkan data. Teknik adalah suatu cara yang strategis untuk mendapatkan suatu tujuan. Maka dari itu, dalam meraih sebuah informasi atau data yang sesuai dengan permasalahan yang diambil, peneliti menggunakan beberapa teknik, yaitu: 1) tes, tes ini dilakukan terhadap siswa kelas X SMA NU Al Fudloli Ganjaran sebagai objek penelitian. Dilakukan tes ini dengan maksud untuk memperoleh dan mengetahui tingkat kemampuan peserta didik dalam menulis hasil observasi. Tes ini lakukan secara berkala dimulai dari 
sebelum memulai teknik pembelajaran sampai setelah teknik pembelajaran dilaksanakan sebanyak tiga kali, 2) observasi, teknik pengumpulan data dengan observasi digunakan apabila, penelitian berkenaan dengan manusia, proses belajar, proses kerja, gejala-gejala alam, dan apabila responden yang diamati tidak terlalu besar. ${ }^{17}$ Dalam hal ini peneliti terjun langsung untuk melakukan sebuah observasi terhadap objek yang diteliti atau terhadap objek yang dijadikan sebagai sumber data.

Dalam sebuah penelitian perlu ada yang namanya analisis data, dengan tujuan untuk meraih kesimpulan dari apa yang mau diangkat menjadi permasalahan dan juga untuk mencari kesimpulan penyelesaian masalah. Analisis data adalah proses mencari dan menyusun secara sistematis data yang diperoleh dari hasil wawancara, catatan lapangan, dan dokumentasi, dengan cara mengorganisasikan data kedalam kategori, menjabarkan kedalam unit-unit, melakukan sintesa, menyusun kedalam pola, memilih mana yang penting dan yang akan dipelajari, dan membuat kesimpulan sehingga mudah difahami oleh diri sendiri maupun orang lain. ${ }^{18}$

Teknik analisis data adalah cara menganalisis data, teknik analisis data dilakukan mulai dari sebelum memasuki lapangan seperti wawancara dengan guru dan sebagainya, selama dilapangan seperti kegiatan pembelajaran saat berlangsung dan sebagainya, dan setelah selesai dilapangan seperti mengorganisasikan hasil data yang diperoleh dan sebagainya. Nasutio menyatakan bahwa analisis telah mulai sejak merumuskan dan menjelaskan masalah, sebelum terjun kelapangan, dan berlangsung terus sampai penulisan hasil penelitian. ${ }^{19}$

Instrumen yang digunakan dalam penelitan ini berupa tes dan nontes. Instrumen yang berupa tes terdiri dari tes menulis hasil observasi dan lembar penilaian, sedangkan nontes berupa catatan lapangan, observasi dan wawancara.

Tes menulis hasil observasi. Tes ini dilakukan terhadap objek penelitian yakni siswa SMA NU Al Fudloli kelas X untuk mengetahui kemampuan peserta didik dalam menulis hasil observasi. Tes ini dilakuykan untuk mengukur kemampuan peserta didik dalam merumuskan ide, gagasan, temuan-temuan sertya pikirannya dalam tulisan deskripsi berupa hasil observasi.

\section{Pedoman penilaian}

\begin{tabular}{|c|c|c|c|}
\hline No & Aspek & Rincian Kriteria & Skor \\
\hline 1 & Isi & $\begin{array}{l}\text { - Isi sangat baik dan sesuai, sangat tepat dengan judul. } \\
\text { - Isi baik dan sesuai, tepat dengan judul. } \\
\text { - Isi cukup baik dan cukup sesuai, cukup tepat dengan judul. } \\
\text { - Isi yang dihasilkan kurang baik dan kurang sesuai, kurang } \\
\text { tepat dengan judul. } \\
\text { - Isi tidak baik dan tidak sesuai, serta tidak tepat dengan judul. }\end{array}$ & $\begin{array}{l}\text { - } 5 \\
\text { - } 4 \\
\text { - } 3 \\
\text { - } 2 \\
\text { - } 1\end{array}$ \\
\hline 2 & Organisasi & $\begin{array}{l}\text { - Satu paragraf mempunyai } 3 \text { atau lebih kalimat penjelas } \\
\text { - Satu paragraf mempunyai } 2 \text { kalimat penjelas. } \\
\text { - Satu paragraf mempunyai } 1 \text { kalimat penjelas yang sesuai }\end{array}$ & $\begin{array}{l}\text { - } 5 \\
\text { - } 4 \\
\text { - } 3\end{array}$ \\
\hline
\end{tabular}

${ }^{17}$ Prof. Dr. Sugiono.Metode Kuantitatif, Kualitatif dan R\&D.Bandung: Alfabeta,2014. hal 145

${ }^{18}$ Sugiono. Memahami Penelitian Kualitatif. Bandung: Alfabeta 2013 hal 89

${ }^{19} \mathrm{Hal} 89$ 


\begin{tabular}{|c|c|c|c|}
\hline & & $\begin{array}{l}\text { - Satu paragraf hanya terdiri dari } 1 \text { kalimat penjelas dan kurang } \\
\text { sesuai } \\
\text { - Satu paragraf hanya terdiri dari kalimat utama tampa kalimat } \\
\text { penjelas }\end{array}$ & $\begin{array}{l}\cdot 2 \\
\bullet 1\end{array}$ \\
\hline 3 & Bahasa & $\begin{array}{l}\text { - } \text { Penggunaan bahasa sangat baku dan sangat efektif } \\
\text { - Penggunaan bahasa baku dan efektif } \\
\text { - Penggunaan bahasa cukup baku dan cukup efektif } \\
\text { - Penggunaan bahasa kurang baku dan kurang efektif } \\
\text { - Penggunaan bahasa tidak baku dan tidak efektif }\end{array}$ & $\begin{array}{l}\text { - } \\
\text { - } 4 \\
\text { - } 3 \\
\text { - } \\
\text { - } 1\end{array}$ \\
\hline 4 & Mekanik & $\begin{array}{l}\text { - Penggunaan tanda baca, huruf kapital dan kata depan sangat } \\
\text { benar atau tepat. } \\
\text { - Penggunaan tanda baca, huruf kapital dan kata depan benar } \\
\text { atau tepat. } \\
\text { - Penggunaan tanda baca, huruf kapital dan kata depan cukup } \\
\text { benar atau tepat. } \\
\text { - Penggunaan tanda baca, huruf kapital dan kata depan kurang } \\
\text { benar atau tepat. } \\
\text { - Penggunaan tanda baca, huruf kapital dankata depan tidak } \\
\text { benar atau tepat. }\end{array}$ & $\begin{array}{l}-5 \\
\text { - } 4 \\
\text { - } 3 \\
\text { - } 2 \\
\text { - } 1\end{array}$ \\
\hline
\end{tabular}

Skor maksimal 20, perhitungan nilai skala 0-100 sebagai berikut

Nilai akhir : Pemerolehan skor X $100=$ Skor maksimal

\section{Tingkat keberhasilan}

\begin{tabular}{|l|l|c|c|}
\hline No & \multicolumn{1}{|c|}{ Nilai } & Jumlah Siswa & Keberhasilan \\
\hline 1 & $90-100$ & & A \\
\hline 2 & $80-89$ & & B \\
\hline 3 & $70-79$ & & C \\
\hline 4 & $50-69$ & & K \\
\hline 5 & $1-49$ & & D \\
\hline \multicolumn{2}{|l|}{ Jumlah Siswa } & \multicolumn{2}{|c|}{20} \\
\hline
\end{tabular}

Observasi digunakan untuk mengamati aktivitas guru mengajar serta aktivitas peserta didik selama penelitian menulis hasil observasi berlangsung. 


\section{HASIL PENELITIAN}

Tujaun penelitian yang pertama dalam penelitian ini adalah mendeskripsikan hasil menulis observasi siswa kelas X SMA NU Al Fudloli. Dalam observasi awal sebelum penelitian diperoleh data keterampilan menulis hasil observasi siswa kelas $\mathrm{X}$ dapat dilihat dari tabel berikut:

Tabel nilai hasil observasi siswa

\begin{tabular}{|c|c|c|c|c|c|c|c|}
\hline \multirow[t]{2}{*}{ No } & \multirow[t]{2}{*}{ Nama } & \multicolumn{4}{|c|}{ Aspek } & \multirow[t]{2}{*}{ skor } & \multirow[t]{2}{*}{ Nilai } \\
\hline & & Isi & Organisasi & Bahasa & mekanik & & \\
\hline 1 & $\mathrm{AH}$ & 4 & 2 & 2 & 3 & 11 & 55 \\
\hline 2 & $\mathrm{AM}$ & 4 & 3 & 3 & 3 & 13 & 65 \\
\hline 3 & $\mathrm{~B}$ & 4 & 3 & 2 & 3 & 12 & 60 \\
\hline 4 & FR & 4 & 3 & 2 & 2 & 11 & 55 \\
\hline 5 & AR & 4 & 3 & 2 & 2 & 11 & 55 \\
\hline 6 & $\mathrm{IH}$ & 4 & 3 & 3 & 2 & 12 & 60 \\
\hline 7 & MS & 4 & 4 & 3 & 3 & 14 & 70 \\
\hline 8 & SP & 4 & 2 & 3 & 3 & 12 & 60 \\
\hline 9 & $\mathrm{R}$ & 4 & 2 & 2 & 3 & 11 & 55 \\
\hline 10 & FA & 4 & 4 & 3 & 3 & 14 & 70 \\
\hline 11 & NL & 4 & 3 & 3 & 3 & 13 & 65 \\
\hline 12 & $\mathrm{NU}$ & 5 & 4 & 3 & 3 & 15 & 75 \\
\hline 13 & LA & 4 & 3 & 2 & 2 & 11 & 55 \\
\hline 14 & PW & 4 & 4 & 4 & 3 & 15 & 75 \\
\hline 15 & WS & 4 & 4 & 2 & 3 & 13 & 65 \\
\hline 16 & VD & 5 & 4 & 3 & 3 & 15 & 75 \\
\hline 17 & SM & 4 & 3 & 2 & 2 & 11 & 55 \\
\hline 18 & FM & 3 & 3 & 2 & 3 & 11 & 55 \\
\hline 19 & IC & 4 & 3 & 2 & 3 & 12 & 60 \\
\hline 20 & $\mathrm{~F}$ & 3 & 3 & 2 & 3 & 11 & 55 \\
\hline \multicolumn{2}{|c|}{ Jumlah } & 80 & 63 & 50 & 55 & 248 & 1240 \\
\hline \multicolumn{2}{|c|}{ Rata-rata } & 4 & 3,15 & 2,5 & 2,75 & 12,4 & 62 \\
\hline
\end{tabular}

Dari tabel tersebut dapat kita ketahui bahwa hasil rata-rata secara keseluruhan dalam keterampilan menulis hasil observasi masih dibawah keriteria ketuntasan minimal yang ditetapkan dalam KD yang bersangkutan. Keriteria ketuntasan minimal dalam KD yaitu 70 . Hasil tersebut menunjukkan bahwa keterampilan menulis hasil observasi siswa kelas X masih kurang optimal. Hanya terdapat 5 siswa yang nilainya sesuai dengan KKM, sedangkan 15 siswa masih di bawah KKM.

Dengan demikian dapat disimpulkan bahwa keterampilan menulis hasil observasi siswa kelas X termasuk dalam kategori K (kurang). Untuk lebih jelasnya bisa kita lihat dalam tabel tingkat keberhasilan berikut:

Tabel 4.2 Tingkat Keberhasilan Siswa 


\begin{tabular}{|l|l|c|c|c|}
\hline No. & \multicolumn{1}{|c|}{ Nilai } & Jumlah Siswa & Keberhasilan & Persentase \\
\hline 1 & $90-100$ & - & A & - \\
\hline 2 & $80-89$ & - & B & - \\
\hline 3 & $70-79$ & 5 & C & $25 \%$ \\
\hline 4 & $50-69$ & 15 & K & $75 \%$ \\
\hline 5 & $1-49$ & - & D & - \\
\hline & Jumlah & 20 & & $100 \%$ \\
\hline
\end{tabular}

Ket:
A : Sangat Baik
B : Baik
C : Cukup Baik
K : Kurang Baik
D : Tidak Baik

Dapat kita lihat bahwa siswa yang mencapai nilai sesuai KKM (70-79) ada 5 peserta didik, sedang 15 siswa lainnya tingkat keberhasilannya masih dibawah KKM atau masih kurang. Hal tersebut disebabkan kerena kurang ketertarikannya siswa untuk menulis yang disebabkan keterbiasaan dalam sistem pembelajaran ceramah atau siswa hanya mendengarkan sekaligus kurangnya motivasi sehinga siswa menjadi malas dalam menulis. Untuk mengatasi hal tersebut, peneliti memiliki inovasi untuk menerapkan sebuah teknik pembelajaran yang menarik, bisa membangkitkan motivasi siswa. Teknik yang dipilih yaitu teknik pohon faktor. Dengan teknik ini diharapkan dapat meningkatkan kemampuan menulis siswa terutama menulis hasil observasi.

Tujaun penelitian yang ke dua dalam penelitian ini adalah mendeskripsikan penerapan teknik pembelajaran pohon faktor dalam menulis observasi. Penerapan teknik pembelajaran pohon faktor dalam menulis observasi memiliki kesamaan dengan teknik jaring laba-laba. Namun dalam jaring laba-laba bentuknya seperti jaring laba-laba, yakni keliling, dalam hal ini ide pokok atau gagasan utama atau topik utama berada ditengah dan dikelilingi oleh sub sub pokok lainnya yang berada dalam ruang lingkup ide pokoknya. Sedangkan teknik pohon faktor bentuknya seperti pohon faktor yang ada dalam pelajaran matematika, dalam hal ini ide pokok atau gagasan utama berada di atas, sedangkan sub sub pokok yang ada diruang lingkup pokok utamnya berada dibawah pokok utama dan seterusnya seperti itu. Lihat gambar berikut. 
Jurnal Tinta, Vol. 1 No. 2, September 2019, Hal. 55-72

Gambar 2.1 Teknik Jaring Laba-laba

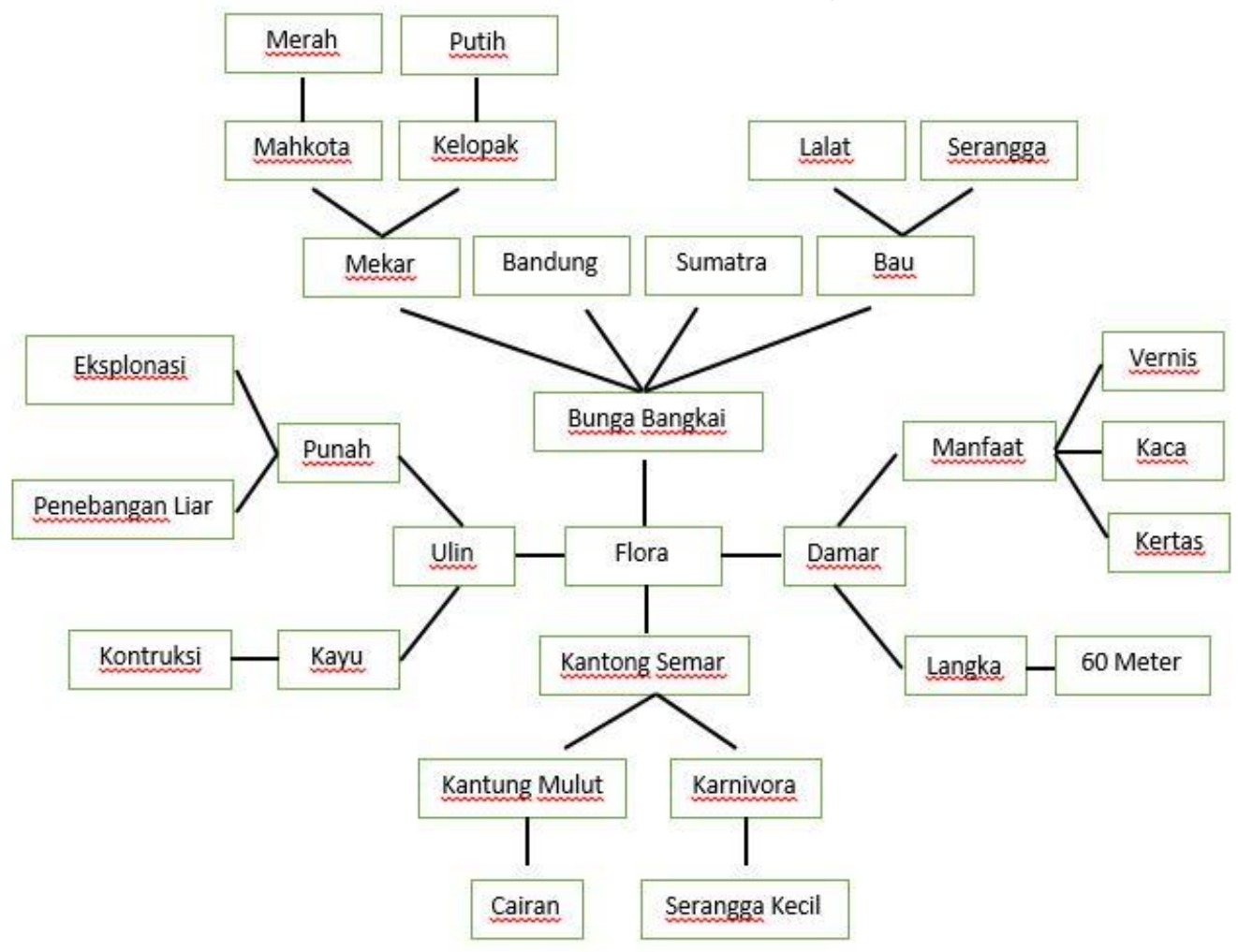

Gambar 2.2 Teknik Pohon Faktor

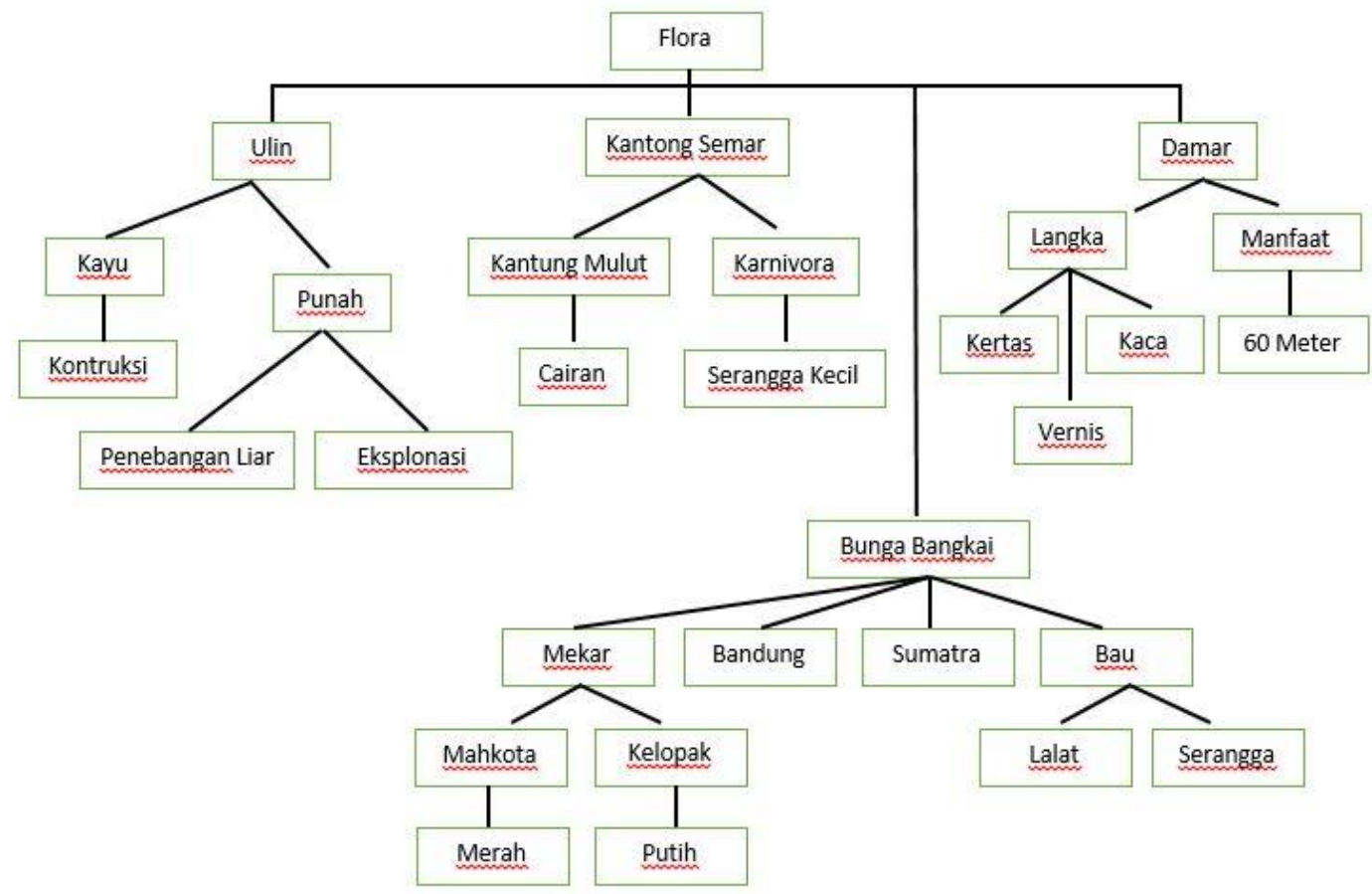


Jadi dapat disimpulkan bahwa teknik pohon faktor adalah suatu cara menulis dengan cara mencari gagasan pokonya terlebih dahulu setelah itu mencarai turunan atau sub pokok yang ada dalam naungan dari gagasan utama tersebut.

Metode ini juga sesuai dengan tuntutan kurikulum 2013 yang mana kegiatan belajarar mengajar berpusat pada siswa tidak lagi ada di guru, dalam k13 guru hanyalah pendamping dan tidak berperan secara aktif. Sedangkan teknik pohon faktor menuntut siswa untuk aktif, kreatif, dan menyenangkan.

Penerapan teknik pohon faktor 1) siswa dibagi menjadi beberapa kelompok, 2) guru memberikan tugas untuk melakukan observasi, 3) setiap kelompok musyawarah menentukan topik atau ide utama yang akan di observasi, 4) setelah mendapatkan topik yang diinginkan, ketua kelompok membagi tugas kepada anggotanya untuk mencari sub sub yang berhubungan atau yang berada dinaungan topik atau ide utama selama waktu yang sudah ditentukan oleh guru, 5) setelah waktu habis, setiap kelompok musyawarah kembali dan menyusun hasil observasi dalam bentuk pohon factor, 6) setelah tersusun menjadi pohon faktor, setiap kelompok menulisakan hasil musyawarahnya yang berbentuk pohon faktor kedalam bentuk laporan hasil observasi, dan 7) perwakilan kelompok maju kedepan untuk mempresentasikan hasil laporannya.

Tujaun penelitian yang ke tiga dalam penelitian ini adalah mendeskripsikan hasil belajar siswa dalam menulis hasil observasi dengan menggunakan teknik pohon faktor pada mata pelajaran bahasa Indonesia di kelas X SMA NU Al Fudloli. hasil belajar siswa dalam menulis hasil observasi dengan menggunakan teknik pohon faktor dalam siklus 1 sebagai berikut.

Hasil penelitian diperoleh dari hasil kerja siswa yang sudah dikerjakannya pada siklus 1. Pada siklus 1 peneliti memberikan tugas untuk membuat laporan hasil observasi. berikut hasil yang diperoleh oleh siswa.

Tabel Nilai Hasil Observasi Siswa Siklus 1

\begin{tabular}{|c|c|c|c|c|c|c|c|}
\hline \multirow[t]{2}{*}{ No. } & \multirow[t]{2}{*}{ Nama } & \multicolumn{4}{|c|}{ Aspek } & \multirow[t]{2}{*}{ skor } & \multirow[t]{2}{*}{ Nilai } \\
\hline & & Isi & Organisasi & Bahasa & mekanik & & \\
\hline 1 & $\mathrm{AH}$ & 4 & 3 & 3 & 3 & 13 & 65 \\
\hline 2 & $\mathrm{AM}$ & 5 & 3 & 3 & 3 & 14 & 70 \\
\hline 3 & B & 5 & 3 & 2 & 3 & 13 & 65 \\
\hline 4 & FR & 4 & 3 & 2 & 2 & 11 & 55 \\
\hline 5 & AR & 4 & 5 & 3 & 2 & 14 & 70 \\
\hline 6 & $\mathrm{IH}$ & 4 & 5 & 4 & 3 & 16 & 80 \\
\hline 7 & MS & 4 & 4 & 3 & 3 & 14 & 70 \\
\hline 8 & SP & 5 & 3 & 4 & 3 & 15 & 75 \\
\hline 9 & $\mathrm{R}$ & 4 & 3 & 3 & 3 & 13 & 65 \\
\hline 10 & FA & 4 & 4 & 3 & 3 & 14 & 70 \\
\hline 11 & NL & 5 & 4 & 4 & 3 & 16 & 80 \\
\hline 12 & $\mathrm{NU}$ & 5 & 4 & 3 & 3 & 15 & 75 \\
\hline 13 & LA & 5 & 4 & 3 & 2 & 14 & 70 \\
\hline 14 & PW & 4 & 4 & 4 & 3 & 15 & 75 \\
\hline
\end{tabular}




\begin{tabular}{|l|l|c|c|c|c|c|c|}
\hline 15 & WS & 4 & 4 & 2 & 3 & 13 & 65 \\
\hline 16 & VD & 5 & 4 & 4 & 3 & 16 & 80 \\
\hline 17 & SM & 4 & 4 & 2 & 3 & 13 & 65 \\
\hline 18 & FM & 4 & 4 & 3 & 3 & 14 & 70 \\
\hline 19 & IC & 4 & 3 & 2 & 3 & 12 & 60 \\
\hline 20 & F & 4 & 3 & 3 & 3 & 13 & 65 \\
\hline \multicolumn{2}{|l|}{ Jumlah } & 87 & 74 & 60 & 57 & 278 & 1390 \\
\hline
\end{tabular}

Dari tabel tersebut dapat kita ketahui bahwa nilai siswa mengalami peningkatan pada siklus 1. Diketahui dari 20 siswa, 12 siswa nilainya sesuai dengan KKM sedangkan 8 siswa lainnya masih dibawah KKM. Bukan hanya nilai siswa yang mengalami peningkat, rata-rata keseluruhan juga mengalami perubahan positif yang semula 62 menjadi 69,5. Dengan begitu rata-rata nilai keseluruhan mengalami peningkatan sebesar 7,5.

Dari tabel di atas dapat diketahui bahwa, hampir semua siswa mengalami peningkatan dalam setiap aspek, hanya ada satu orang yang nilainya masih tetap 55 atau sama dengan nilai pada prasiklus. Dengan demikian dapat dipastikan tingkat keberhasilan cukup berhasil. Hal ini dibuktikan dalam tabel tingkat keberhasilan berikut:

Tabel Tingkat Keberhasilan Siswa Siklus 1

\begin{tabular}{|l|l|c|c|c|}
\hline No. & \multicolumn{1}{|c|}{ Nilai } & Jumlah Siswa & Keberhasilan & Persentase \\
\hline 1 & $90-100$ & - & A & - \\
\hline 2 & $80-89$ & 3 & B & $15 \%$ \\
\hline 3 & $70-79$ & 9 & C & $45 \%$ \\
\hline 4 & $50-69$ & 8 & K & $40 \%$ \\
\hline 5 & $1-49$ & - & D & - \\
\hline & Jumlah & 20 & & $100 \%$ \\
\hline
\end{tabular}

Dari tabel tersebut, dapat diketahui bahwa 3 orang berhasil dengan nilai di atas KKM, 9 orang berhasil dengan nilai sesuai KKM sedangkan 8 orang lainnya masih dibawah KKM, sehingga kemampuan siswa dalam pembelajaran menulis laporan hasil observasi masih perlu ditingkatkan.

Hasil penelitian pada siklus 2. Berikut tabel hasil yang diperoleh oleh siswa pada siklus 2 .

Tabel Nilai Hasil Observasi Siswa Siklus 2

\begin{tabular}{|c|c|c|c|c|c|c|c|}
\hline \multirow[t]{2}{*}{ No. } & \multirow[t]{2}{*}{ Nama } & \multicolumn{4}{|c|}{ Aspek } & \multirow{2}{*}{ skor } & \multirow{2}{*}{ Nilai } \\
\hline & & Isi & Organisasi & Bahasa & mekanik & & \\
\hline 1 & $\mathrm{AH}$ & 4 & 4 & 4 & 3 & 15 & 75 \\
\hline 2 & $\mathrm{AM}$ & 5 & 4 & 4 & 4 & 17 & 85 \\
\hline 3 & B & 5 & 4 & 4 & 4 & 17 & 85 \\
\hline 4 & FR & 4 & 4 & 4 & 3 & 15 & 75 \\
\hline 5 & AR & 5 & 5 & 3 & 4 & 17 & 85 \\
\hline
\end{tabular}




\begin{tabular}{|l|l|c|c|c|c|c|c|}
\hline 6 & IH & 4 & 5 & 4 & 4 & 17 & 85 \\
\hline 7 & MS & 4 & 5 & 4 & 4 & 17 & 85 \\
\hline 8 & SP & 4 & 5 & 4 & 4 & 17 & 85 \\
\hline 9 & R & 4 & 4 & 4 & 4 & 16 & 80 \\
\hline 10 & FA & 5 & 4 & 4 & 4 & 17 & 85 \\
\hline 11 & NL & 5 & 5 & 4 & 4 & 18 & 90 \\
\hline 12 & NU & 5 & 5 & 5 & 4 & 19 & 95 \\
\hline 13 & LA & 5 & 4 & 5 & 3 & 17 & 85 \\
\hline 14 & PW & 5 & 5 & 4 & 4 & 18 & 90 \\
\hline 15 & WS & 5 & 5 & 4 & 4 & 18 & 90 \\
\hline 16 & VD & 5 & 5 & 4 & 5 & 19 & 95 \\
\hline 17 & SM & 4 & 5 & 4 & 4 & 17 & 85 \\
\hline 18 & FM & 5 & 4 & 4 & 4 & 17 & 85 \\
\hline 19 & IC & 4 & 4 & 3 & 4 & 15 & 75 \\
\hline 20 & F & 4 & 4 & 4 & 3 & 15 & 75 \\
\hline \multicolumn{2}{|l|}{ Jumlah } & 91 & 89 & 80 & 77 & 337 & 1685 \\
\hline Rata-rata & 4,55 & 4,45 & 4 & 3,85 & 16,85 & 84,25 \\
\hline
\end{tabular}

Tabel tersebut menunjukkan adanya perubahan positif atau ada sebuah peningkatan yang baik kalau dibandingkan dengan prasiklus/observasi awal maupun siklus 1. Peningkatan itu dibuktikan dengan nilai setiap siswa dan nilai rata-rata keseluruhan yang mencapai 84,25. Sedangkan pada kegiatan prasiklus nilai rata-rata keseluruhan hanya mencapai 62, dan pada kegiatan siklus 1 mencapai 69,5. Maka bisa dikatan bahwa penerapan teknik pohon faktor pada siklus 2 mengalami peningkatan yang baik sekaligus mampu membuat siswa mengalami peningkatan yang baik. Berikut tabel tingkat keberhasilan siswa pada siklus 2 .

Tabel Tingkat Keberhasilan Siswa Siklus 2

\begin{tabular}{|l|l|c|c|c|}
\hline No. & \multicolumn{1}{|c|}{ Nilai } & Jumlah Siswa & Keberhasilan & Persentase \\
\hline 1 & $90-100$ & 5 & A & $20 \%$ \\
\hline 2 & $80-89$ & 11 & B & $55 \%$ \\
\hline 3 & $70-79$ & 4 & C & $25 \%$ \\
\hline 4 & $50-69$ & - & K & - \\
\hline 5 & $1-49$ & - & D & - \\
\hline & Jumlah & 20 & & $100 \%$ \\
\hline
\end{tabular}

Tabel di atas menunjukan keberhasilan siswa dalam menulis laporan hasil observasi. Dari 20 peserta didik, 5 peserta didik mendapat nilai 90-100, 11 peserta didik mendapat nilai 80-89 dan 4 peserta didik mendapat nilai 70-79 atau $100 \%$ peserta didik mendapat nilai sesuai dengan KKM. 


\section{PEMBAHASAN}

Dari hasil observasi awal masih banyak siswa yang mendapatkan nilai dibawah keriteria ketuntasan minimal yang ditetapkan dalam KD yang bersangkutan. Keriteria ketuntasan minimal yang dipatok dalam KD bersangkutan yaitu 70. Dari 20 siswa hanya ada 5 siswa yang nilainya sesuai KKM dan 15 siswa masih di bawah KKM.

Dengan demikian dapat disimpulkan bahwa keterampilan menulis dari hasil observasi siswa kelas $\mathrm{X}$ termasuk dalam kategori $\mathrm{K}$ (kurang) yaitu hanya 25\% yang sesuai dengan KKM dan $75 \%$ yang di bawah KKM.

Penerapan Teknik Pohon Faktor dalam menulis hasil observasi pada siklus pertama: 1) perencanaan: a) peneliti menyiapkan RPP, teknik pohon faktor secara matang yang diterapkan dalam dua ruang, b) peneliti mempersiapkan instrument seperti lembar penilaian, lembar pengamatan, dan menyiapkan kamera untuk memotret jalannya kegiatan pembelajaran. 2) pelaksanaan: a) memberikan apresiasi kepada siswa, b) peneliti memberi kesempatan pada siswa untuk bertanya, c) peneliti membagi kelompok, d) siswa diminta membuat kerangka yang perlu ditulis dalam tulisan hasil observasinya, dan kerangka tersebut dibuat seperti pohon faktor, e) siswa diminta melanjutkan menulis karangan, f) hasil karangan dikumpulkan, g) peneliti dan siswa melakukan refleksi.

Pada siklus pertama dilakukan satu kali pertemuan dengan alokasi waktu 2 x 45 menit dengan pembagian sebagai berikut : 1) kegiatan awal 15 menit. Pada kegiatan ini, peneliti memberi apresiasi kepada siswa, mengondisikan kelas, memberi stimulus pada siswa, serta memberi motivasi, 2) kegiatan inti 60 menit. Dalam kegiatan inti, peneliti membuat kelompok, memberikan tugas kelompok dalam luar ruangan untuk melakukan observasi tentang lingkungan sekolah selama 30 menit, lalu siswa masuk kembali dan mengerjakan tugas selanjutnya dalam kelas selama 30 menit, dan 3) kegiatan penutup 15 menit. Dalam kegiatan penutup, peneliti bersama siswa melakukan refleksi yang terdiri dari evaluasi beserta menyimpulkan hasil pembelajaran yang sudah dilakukan. Dan peneliti menutup pertemuan yang sudah berlangsung.

Hasil pada siklus pertama mengalami peningkatan nilai dari 20 siswa 12 siswa mendapat nilai sesuai dengan KKM dan 8 siswa masih di bawah KKM. Dengan demikian dapat disimpulkan bahwa keterampilan menulis dari hasil observasi awal siswa kelas X mengalami peningkatan sebesar $35 \%$, semula hanya $25 \%$ siswa yang sesuai KKM, pada sikulus pertama terdapat 60\% siswa yang sesuai dengan KKM, dengan rata-rata nilai kelas yaitu 69,5

Penerapan teknik pohon faktor pada siklus ke dua: 1) perencanaan: a) memperbaiki rencana pembelajaran menulis laporan hasil observasi, b) memperbaiki instrumen-instrumen seperti lembar pengamatan, penilaian dan dokumentasi. 2) pelaksanaan: a) memberikan apresiasi kepada siswa, b) peneliti memberi kesempatan pada siswa untuk bertanya, c) peneliti membagi kelompok, d) siswa diberikan tugas di luar kelas dan dalam kelas, e) siswa diminta membuat kerangka yang perlu ditulis dalam tulisan hasil observasinya dan kerangka tersebut dibuat seperti pohon faktor, f) siswa diminta melanjutkan menulis karangan didalam kelas, g) hasil karangan dikumpulkan, dan h) peneliti dan siswa melakukan refleksi.

Pada siklus ke dua dilakukan satu kali pertemuan dengan alokasi waktu 2 x 45 menit dengan pembagian waktu sebagai berikut : 1) kegiatan awal 20 menit. Pada kegiatan ini, peneliti memberi apresiasi kepada siswa, mengondisikan kelas, memberi stimulus pada siswa, serta memberi motivasi, beserta memberikan game yang menarik dan mengarah kepada kegiatan 
pembelajaran. 2) kegiatan inti 60 menit. Dalam kegiatan inti, peneliti membuat kelompok kecil, memberikan tugas kelompok dalam luar ruangan untuk melakukan observasi tentang lingkungan sekolah selama 20 menit, lalu siswa masuk kembali dan mengerjakan tugas selanjutnya dalam kelas selama 20 menit. Laporan hasil observasi ditempelkan pada dinding lalu memberikan kesempatan bagi siswa untuk menilai hasil observasi temannya selama 20 menit. 3) kegiatan penutup 10 menit. Dalam kegiatan penutup, peneliti bersama siswa melakukan refleksi yang terdiri dari evaluasi beserta menyimpulkan hasil pembelajaran yang sudah dilakukan. Dan peneliti menutup pertemuan yang sudah berlangsung.

Hasil pada siklus ke dua mengalami peningkatan nilai dari 20 siswa 20 siswa mendapat nilai sesuai dengan KKM. Dengan demikian dapat disimpulkan bahwa keterampilan menulis dari hasil observasi siswa kelas $\mathrm{X}$ mengalami peningkatan sebesar $40 \%$, semula hanya $60 \%$ siswa yang sesuai KKM pada sikulus pertama, dan terdapat $100 \%$ siswa yang sesuai dengan KKM pada siklus ke dua dengan nilai rata-rata kelas 84,25.

\section{KESIMPULAN}

Berdasarkan hasil penelitian tindakan kelas ini dapat disimpulkan: 1) prasiklus ada 5 siswa yang mendapat nilai sesuai dengan KKM dan 15 siswa mendapat nilai di bawah KKM atau hanya $25 \%$ yang sesuai dengan KKM dan $75 \%$ yang di bawah KKM, 2) Penerapan teknik pohon faktor yaitu dengan mencari gagasan pokok terlebih dahulu kemudian mencarai turunan atau sub pokok yang ada dalam naungan dari gagasan pokok tersebut, kemudian mengembangkan gagasan pokok dan sub pokok menjadi kalimat dan menggabungkannya menjadi paragraf, 3) hasil pada siklus pertama mengalami peningkatan nilai dari 20 siswa 12 siswa mendapat nilai sesuai dengan KKM dan 8 siswa masih di bawah KKM. Dengan demikian dapat disimpulkan bahwa keterampilan menulis dari hasil observasi awal siswa kelas X mengalami peningkatan sebesar 35\%, semula hanya 25\% siswa yang sesuai KKM. Pada siklus pertama terdapat $60 \%$ siswa yang sesuai dengan KKM, dengan rata-rata nilai kelas yaitu 69,5. Hasil pada siklus ke dua mengalami peningkatan nilai dari 20 siswa 20 siswa mendapat nilai sesuai dengan KKM. Dengan demikian dapat disimpulkan bahwa keterampilan menulis dari hasil observasi siswa kelas $\mathrm{X}$ mengalami peningkatan sebesar $40 \%$, semula hanya $60 \%$ siswa yang sesuai KKM pada sikulus pertama, dan terdapat $100 \%$ siswa yang sesuai dengan KKM pada siklus ke dua dengan nilai rata-rata kelas 84,25.

Dengan demikian penerapan teknik pohon faktor dapat meningkatkan keterampilan menulis laporan hasil observasi siswa.

\section{DAFTAR PUSTAKA}

Abidin. Yunus. 2013. Pembelajaran Bahasa Berbasis Karakter. Bandung: Refika Aditama

Asih. 2016. Strategi pembelajaran bahasa indonesia. Bandung: Pustaka Setia

Kundaru dan Slamet. 2014. Pembelajaran Keterampilan Berbahasa Indonesia. Yogyakarta: Graha Ilmu. 
Jurnal Tinta, Vol. 1 No. 2, September 2019, Hal. 55-72

Leo. Sutanto. 2014. Mencerahkan Bakat Menulis. Jakrta: Kompas Gramedia

Rohman dan Sofan. 2013. Strategi dan Desain Pengembangan Sistem Pembelajaran. Jakarta: Prestasi Pustaka

Sugiono. 2008. Penelitian Kuantitatif, Kualitatif dan R\&D. Bandung: Alf Beta

Sugiono. 2015. Metode Kuantitatif, Kualitatif dan R\&D. Bandung: Alfa Beta

Sugiono. 2013. Memahami Penelitian Kualitatif. Bandung: Alfa Beta

Suyadi. 2015. Panduan Penelitian Tindakan Kelas. Jogjakarta: Diva Press

Tarigan. 2008. Menulis Sebagai Suatu Keterampilan Berbahasa. Bandung: Angkasa Bandung

Wikipedia. 2018. Pengamatan. Online. Tersedia:

https://id.wikipedia.org/wiki/Pengamatan yang direkam pada 27 Maret 2018. (di akses pada 25 Maret 2019)

Wina. Sanjaya. 2015. Penelitian Tindakan kelas. Jakarta: Prenadamedia Group

Zuriah. Nurul. 2016. Metodologi penelitian sosial dan pendidikan. Jakarta: Bumi Aksara 